\title{
A Review on Evolution and Controversies Regarding Surgical Methods and Timing of Palatoplasty in UCLP Cases
}

\author{
Meenakshi M. Tiwari ${ }^{1}$, Vikrant V. Jadhav², Ranjit H. Kamble², Pallavi S. Daigavane ${ }^{4}$, Vasudevan S. D. ${ }^{5}$ \\ ${ }^{1}$ Department of Orthodontics and Dentofacial Orthopedics, Sharad Pawar Dental College and Hospital, \\ Sawangi, Wardha, Maharashtra, India. ${ }^{2}$ Department of Orthodontics and Dentofacial Orthopedics, Sharad \\ Pawar Dental College and Hospital, Sawangi, Wardha, Maharashtra, India. ${ }^{3}$ Department of Orthodontics \\ and Dentofacial Orthopedics, Sharad Pawar Dental College and Hospital, Sawangi, Wardha, Maharashtra, \\ India. ${ }^{4}$ Department of Orthodontics and Dentofacial Orthopedics, Sharad Pawar Dental College and \\ Hospital, Sawangi, Wardha, Maharashtra, India. ${ }^{5}$ Department of Orthodontics and Dentofacial \\ Orthopedics, Sharad Pawar Dental College and Hospital, Sawangi, Wardha, Maharashtra, India.
}

\section{ABSTRACT}

\section{BACKGROUND}

To establish speech, growth and development of maxillofacial region and hearing etc. towards normal is the aim of every professional working for cleft care. With a quest to attain and normalize the growth and development in CLP since ages, researchers and workers have invented and still inventing newer technique to treat them. The procedure of surgeries has evolved over a period of time. Controversies concerning speech and maxillofacial growth have challenged many surgeons who have come up with different views in surgical methods. Studies suggest that the palate repair is the main cause of the maxilla and growth disturbance that later is responsible for speech impairment due to fibrous tissue in anterior palate and constricted tissue in uvula due to repair. Many authors have noted that delayed hard palate repair has more positive effects on maxillary growth than that of early hard palate repair, but studies have also proved that late palate repair impair the speech with due respect. This unsolved controversy whether to opt for late/ early palatoplasty w.r.t to the improvement in speech is still unsolved controversy. The purpose of this article is to review the history of cleft palate surgery, its evolution, various surgical methods and optimal timing of cleft palate repair.

\section{KEY WORDS}

Palatoplasty, Fistula, Cleft Lip Cleft Palate, Primary Bone Grafting, Secondary Bone Grafting.
Corresponding Author: Dr. Meenakshi M. Tiwari, Department of Orthodontics and Dentofacial Orthopedics, Sharad Pawar Dental College and Hospital, Sawangi, Wardha, Maharashtra, India. E-mail: drmeenakshigaud@gmail.com

DOI: 10.14260/jemds/2020/54

Financial or Other Competing Interests: None.

How to Cite This Article: Tiwari MM, Jadhav VV, Kamble RH, et al. A review on evolution and controversies regarding surgical methods and timing of palatoplasty in UCLP cases. J. Evolution Med. Dent. Sci. 2020;9(04):236-244, DOI: 10.14260/jemds/2020/54

Submission 12-10-2019,

Peer Review 08-01-2019,

Acceptance 14-01-2020,

Published 27-01-2020. 


\section{Embryological Aspect}

Neural crest cells (NCC) arise from the cranial crest forms the facial primordial. It is a sequence of small buds of tissue which is formed around the region of primitive mouth. (2) Formation of maxillary processes is initiated when NCC migrate in association with ectodermal cells at the area of primitive oral cavity. At $45^{\text {th }}$ day, development of palatal shelves of embryonic life takes place followed by an intrinsic force that is generated within the palatal shelves. When the intrinsic force reaches a threshold limit, it surpasses the force of resistance of tongue. It is formed by the collection and hydration of hyaluronic acid-1. This acid is secreted by formation of epidermal growth factor (EGF) and transforming growth factor beta (TGF). Type I collagen bundles, which runs from the centre of the vertical shelf partly directs the force needed for elevating palatal shelf. (2) Palatal shelf has basement membrane and epithelial covering, which exhibits differential traction and it helps to constrain and redirect the swelling osmotic force. The mesenchymal cells which are present in palatal are contractile in nature and these mesenchymal cells secrete various neurotransmitter, exhibit cell contractility and secrete glycosaminoglycan dehydration. (2) Midline epithelial seam is formed by medial edge epithelial approximation. At this time, palatal shelves fuse with each other developing cell adhesion molecules and desmosomes. During this developmental stage, the palatal shelves rapidly elevate. They change their position from vertical to a horizontal position, which is above the dorsum of the tongue. Time required for self-elevation is probably within minutes or hours.

During the process of expansion, initially there is increase in dimension of epithelial cells, which in turn cell size decreases simultaneously. The process of expansion takes place at oral and nasal aspects with increase in the height of palatal and epithelial cell migration which in turn establishes continuity across the intact horizontal palate. Epithelial cells on medial edge cease DNA synthesis 24-36 hrs prior to shelf contact by the process of apoptosis with intact basement membrane. Based on the experiment conducted on epithelial mesenchymal recombination cells it was concluded that mesenchyme cells specify epithelial differentiation with epithelial cells at medial edge undergo death which is rather a "murder" by the underlying mesenchyme than an intrinsic epithelial suicide. (2)

Mesenchymal cells transmit signals for epithelial differentiation. These are transmitted by firstly through extracellular matrix molecules and soluble factors and direct cell-to cell contact, or combinations of all the above. The fusion of the mesenchymal shelves takes place within minutes, but complications occur during developmental events, which result in a palatal clefting. When large number of epithelial seam cells migrate, it results into seam disruption (perhaps $50 \%$ into the palatal mesenchyme. (2) These cells which are formed very quickly become undistinguishable from other palatal mesenchyme cells.

Myogenic blastemata develop in the soft palate, similarly osteogenic blastemata develop in palatal processes of the maxillary and palatine bones. This blastemata is responsible for differentiation of the mesenchyme of the hard palate. The epithelia on nasal aspect of the palate gets differentiated into pseudostratified ciliated columnar cells. The epithelia on the oral aspect of the palate gets differentiated into stratified squamous nonkeratinized cells. There is almost no growth in width of head, but constant growth in height of head, during palatal shelf elevation. This establishes a favourable orofacial environment for the expansion of palatal shelves to occupy a position above the dorsum of the tongue. On $43^{\text {rd }}$ day palatal shelves elevate (22-24 mm CRL) and is closed till $55^{\text {th }}$ days (33-37 mm CRL). The mesenchymal fusion is complete by $60^{\text {th }}$ days (45-46 $\mathrm{mm}$ CRL).

\section{Historical Perspective from Ancient Times to the Renaissance Period}

Cleft lip and palate (CLCP) research work is carried out extensively in the field of Orthodontics. Many surgical techniques have been developed to correct cleft lip and palate, but till date there are many controversies on treatment approach. It all started with the unresolved work of archaeological department. With their dazzling work on ancient civilization which existed at that time such evidence has been brought into picture. In that era, Schonwerda and Peruvian civilizations have documented the data regarding individuals who were not treated for CLCP. They also noted that these individuals survived till adulthood. (3) But as we know, every coin has another side, the literature by the Egyptians, Mesopotamians, Indians, Greeks and Romans studies, based on archaeological evidence descriptions of cleft operations were not recorded in these civilizations. (4) For many decades, the particular aetiology of CLCP was not identified and diagnosed as tertiary syphilis.

In Chin dynasty (4th century AD), first data regarding surgical treatment of CLCP was recorded. Wherein only procedures to correct the lip was mentioned with no methods for repair of cleft palate was described. To correct the hyper nasal speech covering the palatal defects was done. It was covered with cotton and plates of silver or lead. $(5,6)$ For many years, this technique was used as an obturator to close fistula of palate As during ancient times anaesthesia was not available it was very impossible to operate cleft palate, but during early nineteens with the advent of chloroform the first known cleft palate surgery was performed. (6), (7) The advent anaesthesia led to a new beginning in the field of surgery. In 1764, the first surgical repair of a cleft velum was done by the French dentist, Le Monnier. (8) The operation was done in three-stage. Firstly the cleft edges were approximated with sutures, then cauterization of the cleft edges was done followed by realigning the fresh edges. (9), (6)

In 1828, Johann Friedrich Dieffenbach did surgical repair of cleft palate by elevating the mucosa on the hard palate to close the palatal cleft and, then lateral osteotomies were done to close the defect. (10) Later in the beginning of $19^{\text {th }}$ century the drastic development was seen in the repair of clefts by the techniques employed by Bernhard von Langenbeck in 1859, (11) Victor Veau in 1931, (12) Kilner and William EM Wardill in 1937, (13) wherein bipedicled mucoperiosteal flap was advanced medially to close the cleft palate defect. The enhanced blood supply of the mucoperiosteal flaps considerably decreased the occurrence of dehiscence following palatoplasty which was considered the lacunae in previous surgical technique. Due to this hard work, treatment of CLCP became possible with best outcomes. The treatment aimed to improve midfacial skeletal growth, velopharyngeal insufficiency and speech. 


\section{Techniques of Palatoplasty and Their Modifications}

Bernhard Von Langenbeck Palatoplasty- Bernhard Rudolph Conrad Langenbeck was a renowned surgeon of Germany during mid of $19^{\text {th }}$ century. He was a founder of surgical dynasty born in 1810 in Paddingbuttel a small town near North Sea. (11) The oldest palatoplasty procedure for CLCP was introduced by von Langenbeck in 1859. It was performed in the case of an incomplete cleft of the secondary palate. It was not done if the defect included lip and alveolus. The defect was closed with shortening of the palate. It was performed by mobilizing the bipedicled mucoperiosteal flaps medially. (14) The lateral relaxing incision is given to approximate cleft margins. It initiates from the posterior margins of maxillary tuberosity area. It then continues with the posterior portion of the alveolar ridge (Fig. 1). To create muscle sling, additional procedure such as muscle dissection and muscle suturing is been done. Von Langenbeck technique has several modifications such as intravelar veloplasty to replicate the standard sling of muscles. Also, Furlow double opposing Zpalatoplasty can be used with Langenbeck technique to increase palatal length. (15) (Fig 1.1 - 1.3)

Veau-Wardill-Kilner Palatoplasty- V-Y procedure is done to lengthen the palate and retroposed the whole mucoperiosteal flap and the soft palate. (13) During the V-Y procedure, there is a wide raw area anteriorly and laterally along the alveolar margin which heals by secondary intention. This procedure results in velopharyngeal incompetence and shortening of the palate. Dental malalignment and alveolar arch constriction are the consequences of the bare surface besides the alveolar margin. This procedure is an alteration of the von Langenbeck method. The incision is made beside the cleft margin and the alveolar margin which are combined anteriorly to free the mucoperiosteal flaps. (16), (17) The soft plate is restored in a straight line and are based on the greater palatine vessels. The levator palati muscle separation and re-establishment of the muscle sling is completed as in intravelar veloplasty. (18) (Fig $2.1-2.4$ )

Furlow Double Opposing Z-Palatoplasty- In 1978, double opposing Z-palatoplasty was presented by Leonard T. Furlow Jr. (19) This procedure involves changing the retrogressive flaps with Z-plasties. Within the posteriorly mobilized flaps relocation of the levator veli palatini muscle is done. Incisions are made along margins of cleft to close the hard palate region, taking the benefit of deep arch of the palate the mucoperiosteum is elevated from the medial side, hence cleft is closed by layers without any additional lateral incision. Marginal velopharyngeal insufficiency and primary closure of a submucous cleft palate is very well addressed with this procedure. (19), (20) (21), (22), (23), (24), (25) On transposition of the triangles, the suture line is horizontal with good overlap of the levator muscle providing effective lengthening of the soft palate and speech outcome. However, the studies have not proved this objectively. The major drawback of the technique is the non-anatomic placement of the muscle.

Two-Stage Palatoplasty- Two-stage Palatoplasty was first described in 1967 by Janusz Bardach in Poland. It is a recognized fact that unrepaired cleft patients have acceptable maxillary relationship and development. (26), (27), (28) Due to early palatal surgical intervention, maxillary hypoplasia which occurred in anteroposterior direction therefore, many surgeons began to perform palate repair in two stages. First the soft palate was repaired followed by hard palate. (29) Schweckendiek advocated early closure of the soft palate and delayed closure of the hard palate by introducing a new protocol for better upper jaw growth. (29) He advocated both lip and soft palate surgeries to be done at the 4-6 months. He advised to cover hard palate with a prosthetic plate. After this at the age of 12-15 years, surgery should be done. He believed that normal speech and normal maxilla growth can be achieved by following such protocol. Rohrich et al. noted that if the palate is repaired early by two-stage repair procedure then complete closure of the cleft was addressed till 15-18 months of age. (30) Perko et al also revised the protocol for twostage palatoplasty. He advised soft palate repair at 18 months and hard palatal repair at 5-6 years of age. He observed a compromised speech with these individuals. (31) Hence, this technique fell into disrepute. Delaire et al introduced twostage functional palatoplasty in which the cleft palate repair was described. His technique was based on a soft and hard palate defect closure. (32) Anatomic location of the greater palatine neurovascular pedicle is important to achieve greater versatility to shield the defect. (Fig. $3.1-3.5$ )

Hole in One Repair- Prof. K. S. Goleria gave the term 'hole in one' which seems to be taken from terms used in Game of Golf. Repeated hospitalization for cleft lip and cleft palate surgeries in developing countries is a disadvantage for individual. To overcome this drawback, surgeons came up with single step repair of the entire cleft defect in more than 10 months age children. Some surgeons found exceptionally better outcome with least complications. However, results have shown that during closure for wide cleft lip and palate using Hole in one procedure, the alveolar region will have only one layer closure which is likely to result in fistula. (33), (34)

Raw Area Free Palatoplasty- This procedure is similar to twoflap palatoplasty, where in the palatal lengthening is performed by the nasal mucosa back-cut. However, the raw area is enclosed with the vomer flap or the buccal mucosal flap. Attempt is made on the oral side to suture all the lateral incisions, so that no raw area is left on either surface. (35) The advantage of the technique is that healing of the palate occurs with primary intention, hence secondary deformities and shortening of the palate is less likely to occur.

Intravelar Veloplasty- Braithwaite first described the dissection of the Levator Palati from the posterior border of the hard palate, nasal and oral mucosa and posterior repositioning in 1968. To achieve velopharyngeal competence, levator muscle repositioning during palatoplasty is the most widely done. He advised to perform reconstruction of the Levator sling with independent suturing of the muscle with that of the opposite side. (36) Since then intravelar veloplasty has evolved considerably. Many modifications are done by surgeons to achieve improved anatomical muscle sling reconstruction. Sommerlad et al advised radical muscle dissection under a microscope. Cutting and Sommerlad advocated the new procedure for radical intravelar veloplasty. 
(37), (38) This procedure subsequently repositions the muscle at the hamulus region. This includes the separation of the tensor palatini tendon, levator palatine belly and sutures. This is done because Levator is the dominant muscle for elevation of the soft palate during speech. (38) Hassan et al a did a study to compare three-layer palatoplasty (Kriens technique) with intravelar veloplasty versus two-layer palatoplasty (WardillKilner) pushback palatoplasty without intravelar veloplasty. Velopharyngeal competency was well addressed with palatal muscle reconstruction and also had acceptable speech and eustachian tube function. (39) (Fig. 4.1)

Alveolar Extension Palatoplasty- Michael Carsten in the year 2011 introduced alveolar extension palatoplasty (AEP) technique for palatoplasty. This technique involves the entire lingual gingiva-periosteal tissue, which is incorporated into the mucoperiosteal flap. This in turn is expected to lengthen and widen the flap for covering larger defects. Michael Carsten states that this technique is more advantageous to angiosomes. The outcome of surgery with this technique is expected to reduce the maxillary hypoplasia. (40)

Primary Pharyngeal Flap- The primary pharyngeal flap given by Richard Stark in 1960 with Dehaan Stark propagated in the western world. He performed this procedure on 1-year old child and by around 1954, he did 60 primary flaps in combination with von langenbeck procedure Before this technique, the soft palate was repaired along with the lip at around 4-6 months of age. Hard palate was repaired at the age of 10-12 years which was later reduced to 4-5 years. Due to this interval, there was reduction in the cleft width at the hard palate region and was easy to close without the need for extensive dissection. This simultaneously decreased the incidence of the maxillary hypoplasia significantly. Primary Pharyngeal Flap is performed to facilitate speech.

Vomer Flaps- Pichler in 1926, introduced the new approach for palatal closure as vomer mucoperiosteal flap. (41) The design of first vomer flap was inferiorly based. A high incision was made on the nasal septum area followed with reflection of the flap in downward direction. This was done for single-layer closure. Vomer-premaxillary sutures gets injured in this procedure causing maxillary retrusion and a high fistula rate. (42), (43), (44) These drawbacks were overcome with superiorly based vomer flap. Vomer flaps procedures involves reflecting the mucosa from cleft margin which are close to the septum for achieving complete closure of the nasal mucosa. A unique feature associated with vomer mucoperiosteal tissue i.e., versatility. Superiorly based turnover flap is basically used for closure of hard palate defect anteriorly and the alveolar area. Several modifications of this for CLCP are for nasal lining and oral mucosa resurfacing. (45)

Buccal Myomucosal Flap- Mukherjee MM in 1969 introduced the Buccal myomucosal flap. This technique was introduced to manage the raw area left over the nasal surface after VeauWardill palatoplasty. Simultaneously, he advocated bilateral buccal mucosal flaps for covering the oral and nasal surfaces. (46) Jackson et al popularized this technique for covering the defect created after back-cut at the junction between hard and soft palate. (47)

\section{Controversies}

Ideal time for cleft palate repair is still under controversy. These surgeries planned to achieve better maxillary growth and good speech outcomes. The timing of palatoplasty should be personalized individually, with the help of clinical evaluation. (48) Delayed surgeries are advised in individuals with airway complications, neuromuscular problems and cardiac anomalies. If needed, these individuals should undergo palatoplasty only special circumstances with proper counselling of parents. (49) Emory and colleagues observed that there was a relation between child's age and rate of fistulas repair. They concluded that individuals who underwent fistula repair before 1 year had 8 percent rate of fistula formation and 19 percent rate after 2 years. Similarly, Rohrich et al (50) observed 5 percent rate at 10 months and 35 percent rate of fistula formation after 4 years.

Proponents of early repair of cleft palate advised surgeries before the 1 year of age to aid in speech development as the speech process in children is initiated at the age 12 months. (51), (52), (53), (54) Many surgeons observed that delayed palatal closure results in better maxillofacial growth but speech development is hampered. (55) This led to the belief that this would be benefit the patients of cleft palate and agreed that the better speech development is compared with palatal repair during language skill acquisition. This development occurred before 12 months. (56), (57) The incidence of velopharyngeal insufficiency following palatoplasty documented to have favourable influence. (Table 1). (58), (21), (39), (59) to achieve a good result proper selection of surgical procedure and its standardization should be done.

On the contrary, there were surgeons, who advocate delayed palatal repair. This was done to facilitate proper maxillofacial growth. They supported the theory that facial growth in transverse direction is completed by 8-9 years of age. (8), (29), (30), (31), (60), (61) Studies done on lip repair and palatoplasty concluded that early lip surgery would hamper antero-posterior growth of the upper jaw, but this was not the case. It was observed that palatoplasty had more drastic effects. In patients who had repair of cleft palate, have transverse maxillary arch deficiency and may require orthodontic treatment. Kaplan et al. (51) Advised palate surgery at 3 to 6 months of age. Dorf and Curtin (57) concluded that early palatoplasty resulted in development of compensatory patterns in 10 percent of individuals and late palatoplasty resulted in misarticulations in 86 percent of the individuals.

It is recommended that palatal repair be done before 24 months. (62), (63) With the evidence of studies, the current conclusion regarding closure timing for palatal repair should be before 18 months. (15) In Riley Hospital for Children, Indianapolis, primary palatoplasty is performed in a single stage between 9 and 12 months of age. (53) However, at the University of Texas in Southwest, recommends a two-stage palatoplasty wherein surgery with soft palate to be repaired at 3 to 6 months and hard palate repair to be done at 15 to 18 months of age. (30) The Furlow Z-palatoplasty is the most commonly used technique for primary palatoplasty as a result of its better outcomes in improving speech and maxillary growth. (15), (19), (20), (62), (63) In the many craniofacial center, the current treatment protocol is to repair the cleft palate between 6 and 12 months of age. For isolated cleft palate, a preferred timing is 6 months of age and for cleft lip and palate patients a preferred timing is 9 to 10 months of age. Two techniques are 
mostly favoured for primary palate repair, Bardach-Salyer two-flap palatoplasty and a Furlow Z-palatoplasty.

\section{Optimal Timing of Cleft Palate Closure}

The American Cleft Palate/Craniofacial Association have developed the Parameters of Care in 1993 which outlines discipline specific treatment needs and suggested timelines for optimal timing of surgery.

\section{Primary CLCP Surgery}

1. Pre-surgical maxillary orthopaedic should be performed.

2. The palate repair to be done before 18 months.

3. Individuals of submucous clefts with speech, feeding and hearing problems undergo palatal repair.

\section{Secondary CLCP Surgery}

1. Symptomatic fistulas should be repaired.

2. The timing of graft should be planned based on dental development and it should be done before eruption of permanent maxillary teeth in the region of the cleft.

3. Enlarged tonsils or adenoids should be operated by tonsillectomy and/or adenoidectomy procedure to allow good adaptability of pharyngeal flap.

The topics of controversy is between the palatal surgery and its influence on growth of maxilla. (64), (65) Surgically repairing the lip and alveolus may be damaging as it causes impaired growth. (66) Each cleft case is dissimilar from another and case-based protocol should be followed. This should be dependent on the severity of defect. (67), (26) Growth disharmony are with CLCP and with an isolated CP closure. (29), (68) Orthodontic approach is followed for transverse (alveolar arch) growth problems. Mostly, anteroposterior and vertical problems are solved with surgical approach. Separate protocol should be followed for isolated cleft $\mathrm{CP}$, as it has different growth alteration than CLCP, in which maxillary growth is more adversely affected. (69), (70)

Gillies and Fry in 1921, (71), (72) did a study in 10 treated cases of CLCP. They noted that there is backward movement and narrowing of maxillary posterior segment and defect was managed with prosthesis. Walter, Hale (73) and Poupard et al., have observed significant results for craniofacial growth who did not went orthodontic treatment which used Gillies-Fry protocol. (74) In 1925, Rayner et al (75) did a study to evaluate changes in the hard palate. He observed 125 CLCP cases and concluded that repair done in 24 months resulted in increased facial growth disturbances than repair at 3 or 4 years of age. Hagemann et al (76) and Schweckendiek also, advised delayed closure of the hard palate. In 1954, Bardach et al. Jolleys et al (77) and Robertson (78), (79) who observed insignificant growth difference in various age group in maxillary arch. Koberg and Koblin (80) in 1033 patients observed that the maximum growth disturbances came from the Veau pushback method, followed by two-stage operation of soft palate and hard palate repair after 1-2 years of age and 12 years respectively along with the relaxing incisions of Von Langenbeck method and found the least amount of facial retrusion. Jolleys (80) observations confirmed the adverse effects of the pushback technique. But Aduss (81) and Bishara et al. ${ }^{(71)}$ observed that when V-Y pushback method was used no statistically significant difference was seen in facial growth. The planned advantage of $\mathrm{V}-\mathrm{Y}$ pushback is to increase the palatal length and accomplish better speech. This supposed advantage has not been substantiated. (82), (83) V-Y pushback was associated with increased risk of midfacial retrusion, arch collapse, palatal fistula and no improvement in speech. The advantage detected with pushback method is actually consequence of the release of the abnormal attachments of the levator and palatopharyngeal muscles and the re-formation of the levator sling than from a growth in actual length.

Braithwaite and Maurice were the surgeons who first proposed that repair of the levator veli palatini as an aide to palatal repair. Soft palate muscle release, retro positioning, and reconstruction of the muscle sling without a hard palate pushback achieved the preferred functional augmentation in the patients. It was observed that the anterior scar of the pushback improved velar function and speech development, without affecting the growth. It was observed that the foremost restraining factor leading to facial growth restriction is not the timing of the cleft palate repair instead, it is the type of surgery that cause the deformity. During the rapid phase of maxillary growth, severe deformities were observed in children who underwent palatal surgeries between the ages of 8 to 12 years. (Table 1 )

\begin{tabular}{|c|c|c|}
\hline Technique & Age of Palatoplasty & $\begin{array}{c}\text { Incidence of VPI (\%) } \\
\text { (Secondary } \\
\text { Velopharyngeal } \\
\text { Surgery) }\end{array}$ \\
\hline $\begin{array}{c}\text { (Marrinan EM et al) Von } \\
\text { Langenbeck palatoplasty }\end{array}$ & 8 months to > 16 months & $14 \%$ \\
\hline VY pushback palatoplasty & 8 months to > 16 months & $15 \%$ \\
\hline $\begin{array}{c}\text { (Salyer KE et al) Two flap } \\
\text { palatoplasty } \\
\text { VY pushback palatoplasty }\end{array}$ & Before 12 months & $8.92 \%$ \\
\hline $\begin{array}{c}\text { (D LaRossa et al) Furlow Z } \\
\text { palatoplasty }\end{array}$ & 10 months & $6.5 \%$ \\
\hline $\begin{array}{c}\text { (Sommerlad BC) Intravelar } \\
\text { veloplasty) }\end{array}$ & Before 12 months & $4.6 \%$ \\
\hline \multicolumn{2}{|c|}{ Table 1. Technique, Age (Timing) and incidence of VPI } \\
\hline
\end{tabular}

\section{Surgical Technique- Pictorial Presentation}

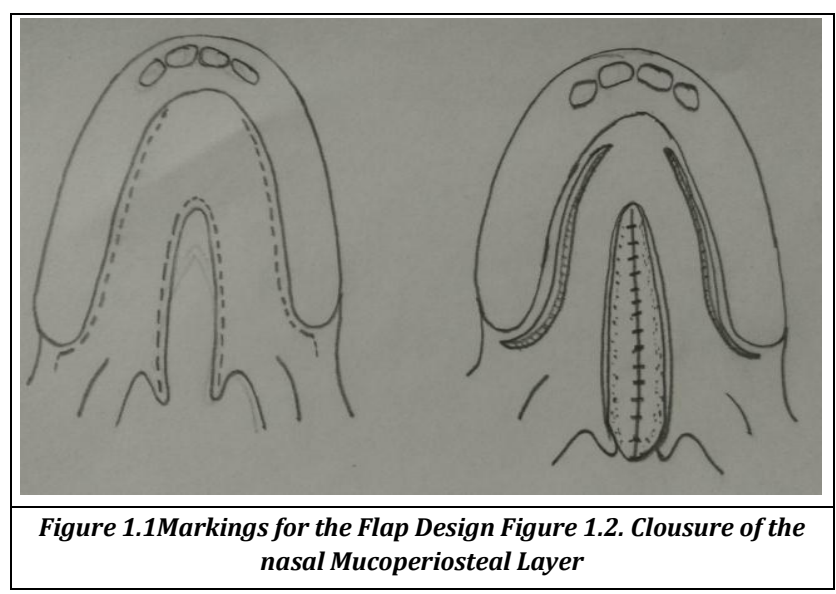




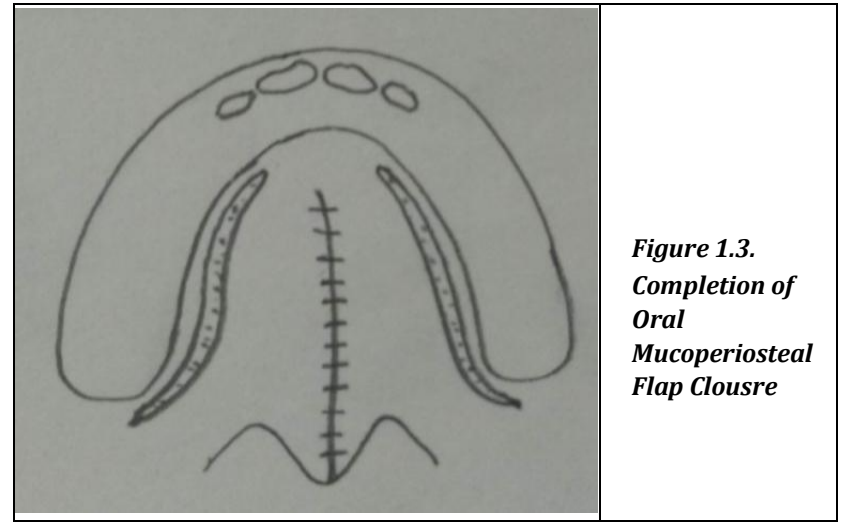

\section{Veau-Wardill-Kilner Palatoplasty}

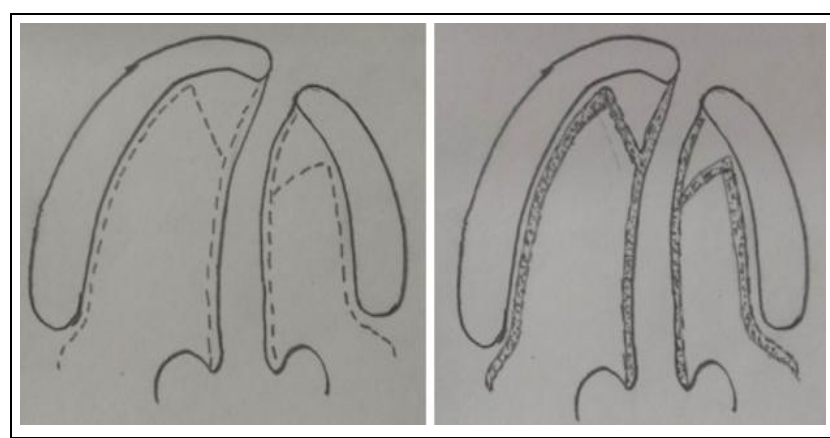

Figure 2.1. Marking for the Incisions. Figure 2.2 Oral Mucoperiosteal Flops Raise with preservation of the greater Palatine Vessels on Both Sides.

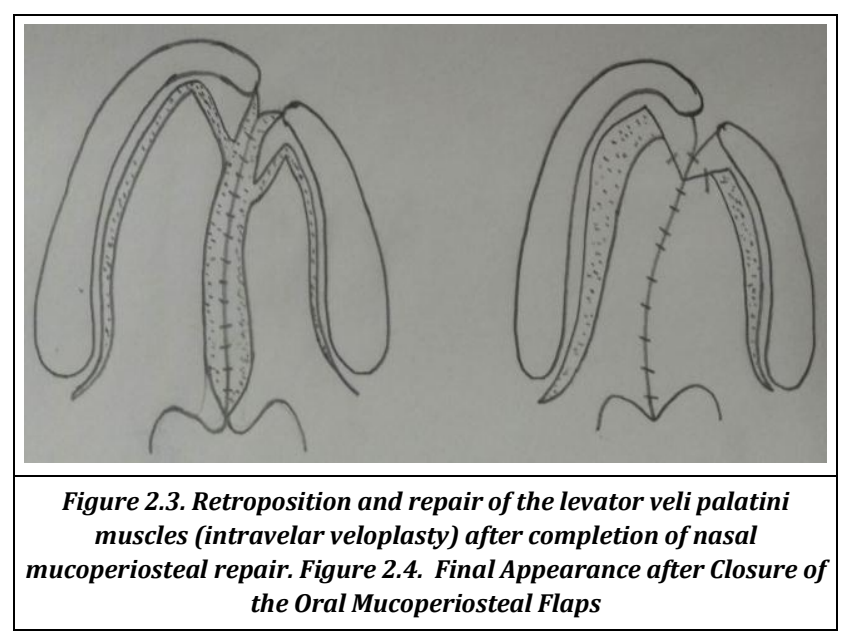

\section{Two-Stage Palatoplasty}

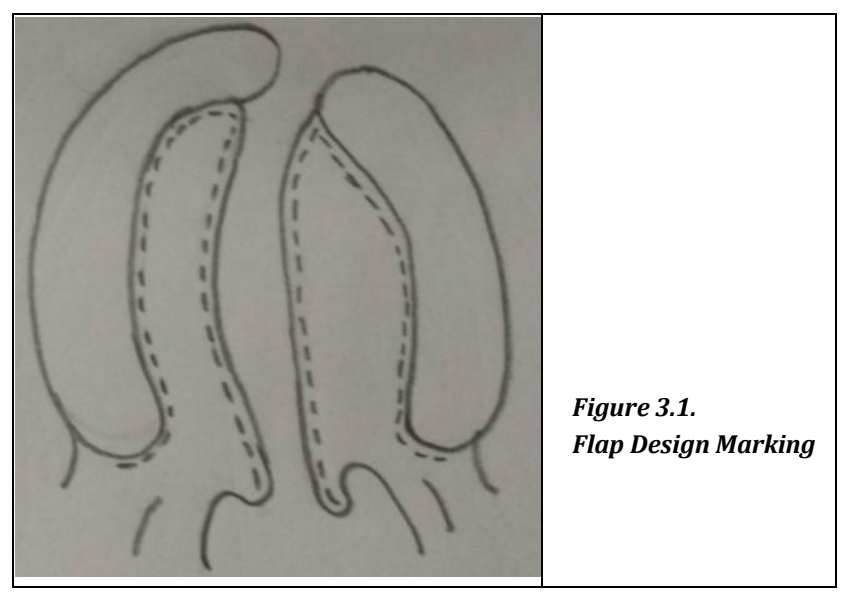

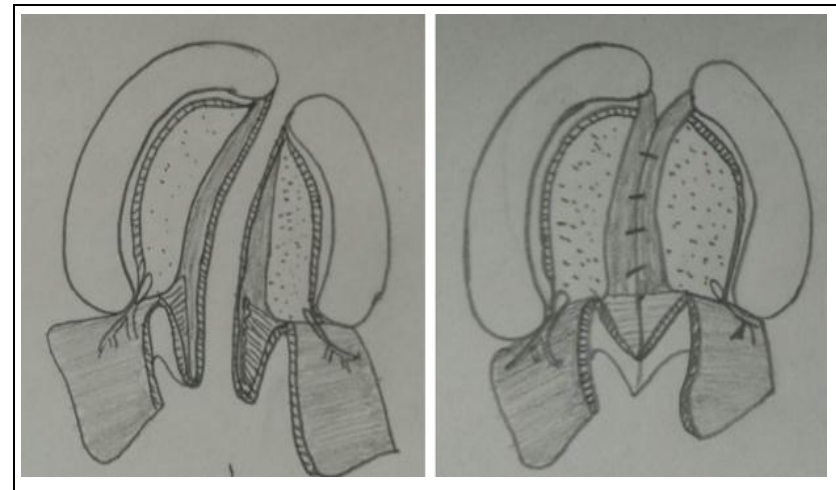

Figure 3.2. Elevation of two mucoperiosteal flaps 3.3. Retroposition and Repair of the Levator Veli Palatine Muscles (Intravelar Veloplasty) After Completion of the Nasal Mucoperiosteal Repair

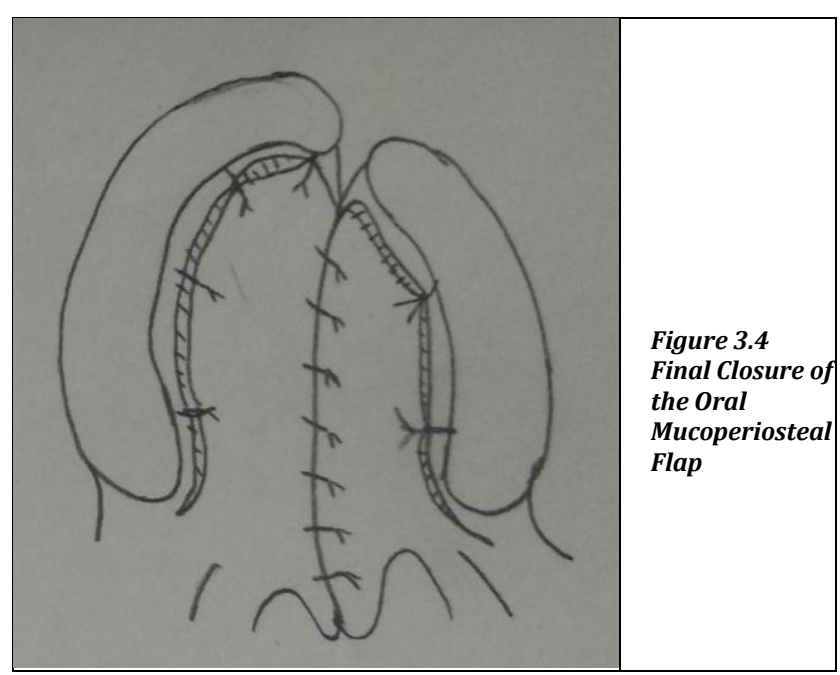

\section{Intravelar Veloplasty}

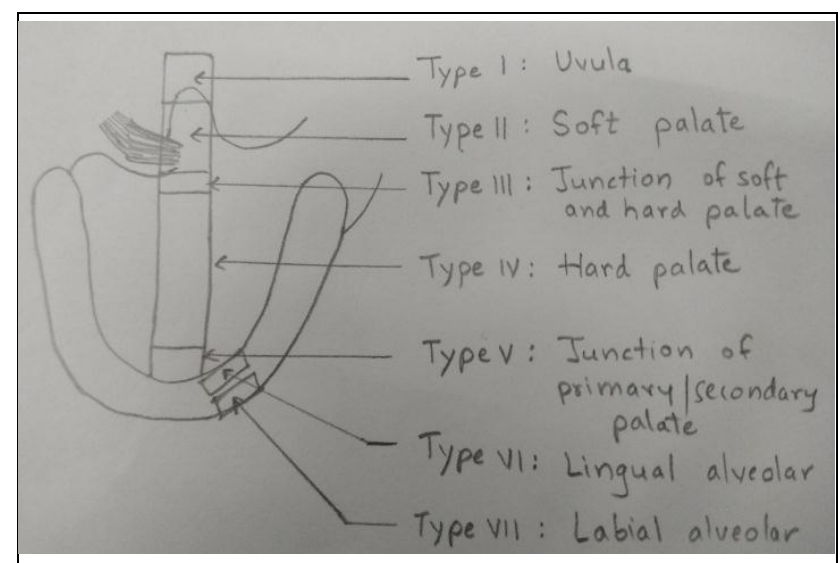

Figure 4.1. Intravelar Veloplasty, Type I. Uvula, Type II. Soft Palate, Type III. Junction of the Soft, Type IV. Hard Palate, Type V. Junction of the Primary/Secondary Palate, Type VI. Lingual Alveolar, Type VII. Labial Alveolar

\section{REFERENCES}

[1] Calzolari E, Bianchi F, Rubini M, et al. Epidemiology of cleft palate in Europe: implications for genetic research. Cleft Palate-Craniofacial J 2004;41 (3):244-9.

[2] Ferguson MW. Palate development. Development 1988; (Suppl 103):41-60. 
[3] Bill J, Proff P, Bayerlein T, et al. Treatment of patients with cleft lip, alveolus and palate - a short outline of history and current interdisciplinary treatment approaches. J Craniomaxillofac Surg 2006; (34 Suppl 2):17-21.

[4] Perko M. The history of treatment of cleft lip and palate. Prog Pediatr Surg 1986;20:238-51.

[5] Boo-Chai K. An ancient Chinese text on a cleft lip. Plast Reconstr Surg 1966;38 (2):89-91.

[6] Rogers BO. History of cleft lip and palate treatment. In: Grabb WC, edr. Cleft lip and palate. Boston: Little, Brown \& Company, 1971.

[7] Rogers B, McDowell F. Cleft palate surgery prior to 1816. Source Book Plast Surg 1977: p. 248.

[8] Millard DR. Cleft craft: the evolution of its surgery. $1^{\text {st }}$ edn. Boston: Little, Brown \& Company, 1976: p. 3.

[9] McDowell F. Graefe's first closure of a cleft palate. Plast Reconstr Surg 1971;47 (4):375-6.

[10] Schultheiss D, Knoner W, Kramer FJ, et al. Johann Friedrich Dieffenbach (1794-1847) as the founder of Plastic and Reconstructive Surgery. His contribution to maxillofacial surgery. Mund Kiefer Gesichtschir 1998;2 (6):309-15.

[11] Goldwyn RM. Bernhard Von Langenbeck. His life and legacy. Plast Reconstr Surg 1969;44 (3):248-54.

[12] Veau V. Division palatine: anatomie chirurgie, phonetique. Paris: Masson et cie 1931.

[13] Wallace AF. A history of the repair of cleft lip and palate in Britain before World War II. Ann Plast Surg 1987;19 (3):266-75.

[14] Strong EB, Buckmiller LM. Management of the cleft palate. Facial Plast Surg Clin North Am 2001;9 (1):15-25, vii.

[15] LaRossa D. The state of the art in cleft palate surgery. Cleft Palate Craniofac J 2000;37 (3):225-8.

[16] Bardach J, Salyer KE, Randall P. Surgical techniques in cleft lip and palate. Second Edition. Plast Reconstr Surg 1992;90 (1):130.

[17] Bardach J. Two-Flap palatoplasty: Bardach's technique. Operative Techniques in Plastic and Reconstructive Surgery 1995;2 (4):211-4.

[18] Seckel NG. The palatal island flap on retrospection. Plast Reconstr Surg 1995;96 (6):1262-8: discussion 1269-70.

[19] Furlow JL. Cleft palate repair by double opposing Z-plasty. Plast Reconstr Surg 1986;78 (6):724-38.

[20] Randall P, LaRossa D, Solomon M, et al. Experience with the Furlow double-reversing Z-plasty for cleft palate repair. Plast Reconstr Surg 1986;77 (4):569-76.

[21] LaRossa D, Jackson OH, Kirschner RE, et al. The children's hospital of Philadelphia modification of the furlow double-opposing Z-palatoplasty: long-term speech and growth results. Clin Plast Surg 2004;31 (2):243-9.

[22] Cho BC, Kim JY, Yang JD, et al. Influence of the furlow palatoplasty for patients with submucous cleft palate on facial growth. J Craniofac Surg 2004;15 (4):547-54.

[23] Kitagawa T, Kohara H, Sohmura T, et al. Dentoalveolar growth of patients with complete unilateral cleft lip and palate by early two-stage Furlow and push-back method: preliminary results. Cleft Palate Craniofac J 2004;41 (5):519-25.

[24] Chen PK, Wu J, Hung KF, et al. Surgical correction of submucous cleft palate with Furlow palatoplasty. Plast Reconstr Surg 1996;97 (6):1136-46: discussion 1147-9.
[25] Chen PK, Wu JT, Chen YR, et al. Correction of secondary velopharyngeal insufficiency in cleft palate patients with the Furlow palatoplasty. Plast Reconstr Surg 1994;94 (7):933-41: discussion 942-3.

[26] Ortiz-Monasterio F, Alfonso SR, Gustavo BP, et al. A study of untreated adult cleft palate patients. Plast Reconstr Surg 1966;38 (1):36-41.

[27] Boo-Chai K. The unoperated adult bilateral cleft of the lip and palate. Br J Plast Surg 1971;24 (3):250-7.

[28] Mars M, Houston WJB. A preliminary study of facial growth and morphology in unoperated male unilateral cleft lip and palate subjects over 13 years of age. Cleft Palate J 1990;27 (1):7-10.

[29] Schweckendiek W, Doz P. Primary veloplasty: long-term results without maxillary deformity. A twenty-five year report. Cleft Palate J 1978;15 (3):268-74.

[30] Rohrich RJ, Rowsell AR, Johns DF, et al. Timing of hard palatal closure: a critical long-term analysis. Plast Reconstr Surg 1996;98 (2):236-46.

[31] Perko M. Two-stage palatoplasty. Multidisciplinary management of cleft lip palate. Philadelphia, PA: WB Saunders 1990: p. 311-5.

[32] Markus AF, Smith WP, Delaire J. Primary closure of cleft palate: a functional approach. Br J Oral Maxillofac Surg 1993;31 (2):71-7.

[33] Lehman JJ, Douglas BK, Ho WC, et al. One-stage closure of the entire primary palate. Plast Reconstr Surg 1990;86 (4):675-81.

[34] Goleria KS. Hole in one procedure. In: Presentations during the Workshops, Annual conferences of Indian Society of Cleft Lip Palate and Craniofacial Anomalies and Association of Surgeons of India.

[35] Agrawal K. Raw area free palatoplasty. Presented at "CLEFT 2005" $8^{\text {th }}$ International Congress of Cleft Lip and Palate. Durban, South Africa: 2005.

[36] Braithwaite F, Maurice DG. The importance of the levator palati muscle in cleft palate closure. Br J Plast Surg 1968;21 (1):60-2.

[37] Cutting CB, Rosenbaum J, Rovati L. The technique of muscle repair in the cleft soft palate. Oper Tech Plast Reconstr Surg 1995;2 (4):215-22.

[38] Sommerlad BC, Henley M, Birch M, et al. Cleft palate rerepair-a clinical and radiographic study of 32 consecutive cases. Br J Plast Surg 1994;47 (6):406-10.

[39] Sommerlad BC. A technique for cleft palate repair. Plast Reconstr Surg 2003;112 (6):1542-8.

[40] Carstens MH. Sequential cleft management with the sliding sulcus technique and alveolar extension palatoplasty. J Craniofac Surg 1999;10 (6):503-18.

[41] Pichler H VIII. Zur operation der doppelten lippengaumenspalten. Dtsch Z Für Chir 1926;195 (1):104-7.

[42] Delaire J, Precious D. Avoidance of the use of vomerine mucosa in primary surgical management of velopalatine clefts. Oral Surg Oral Med Oral Pathol 1985;60 (6):589-97.

[43] Friede H, Johanson B. A follow-up study of cleft children treated with vomer flap as past of a three-stage soft tissue surgical procedure: facial morphology and dental occlusion. Scand J Plast Reconstr Surg 1977;11 (1):45-57.

[44] Mølsted K, Palmberg A, Dahl E, et al. Malocclusion in complete unilateral and bilateral cleft lip and palate. The results of a change in the surgical procedure. Scand J Plast Reconstr Surg Hand Surg 1987;21 (1):81-5. 
[45] Agrawal K, Panda KN. Use of vomer flap in palatoplasty: revisited. Cleft Palate Craniofac J 2006;43 (1):30-7.

[46] Mukherji MM. Cheek flap for short palates. Cleft Palate J 1969;6 (4):415-20.

[47] Jackson IT, Moreira-Gonzalez AA, Rogers A, et al. The buccal flap-a useful technique in cleft palate repair? Cleft Palate Craniofac J 2004;41 (2):144-51.

[48] Jones MC. Etiology of facial clefts: prospective evaluation of 428 patients. Cleft Palate J 1988;25 (1):16-20.

[49] Dell'Oste C, Savron F, Pelizzo G, Sarti A. Acute airway obstruction in an infant with Pierre Robin syndrome after palatoplasty. Acta Anaesthesiol Scand 2004;48 (6):787-9.

[50] Rohrich RJ, Love EJ, Byrd HS, et al. Optimal timing of cleft palate closure. Plast Reconstr Surg 2000;106 (2):413-21, quiz 422: discussion 423-5.

[51] Kaplan I, Ben-Bassat M, Taube E, et al. Ten-year follow-up of simultaneous repair of cleft lip and palate in infancy. Ann Plast Surg 1982;8 (3):227-8.

[52] Randall P, LaRossa DD, Fakhraee SM, et al. Cleft palate closure at 3 to 7 months of age: a preliminary report. Plast Reconstr Surg 1983;71 (5):624-8.

[53] Peterson-Falzone SJ. The relationship between timing of cleft palate surgery and speech outcome: What have we learned and where do we stand in the 1990s? - Seminars $\begin{array}{lll}\text { in } \quad \text { Orthodontics } 1996 ; 2 & \text { (3):185-91. }\end{array}$ https://www.semortho.com/article/S1073-8746 (96)80013-2/abstract

[54] Semb G. A study of facial growth in patients with unilateral cleft lip and palate treated by the Oslo CLP team. Cleft Palate Craniofac J 1991;28 (1):1-21, discussion 46-8.

[55] Cosman B, Falk AS. Delayed hard palate repair and speech deficiencies: a cautionary report. Cleft Palate J 1980;17 (1):27-33.

[56] Chapman KL, Hardin MA. Phonetic and phonologic skills of two-year-olds with cleft palate. Cleft Palate Craniofac J 1992;29 (5):435-43.

[57] Dorf DS, Curtin JW. Early cleft palate repair and speech outcome. Plast Reconstr Surg 1982;70 (1):74-81.

[58] Salyer KE, Sng KWE, Sperry EE. Two-flap palatoplasty: 20year experience and evolution of surgical technique. Plast Reconstr Surg 2006;118 (1):193-204.

[59] Marrinan EM, Labrie RA, Mulliken JB. Velopharyngeal function in nonsyndromic cleft palate: relevance of surgical technique, age at repair and cleft type. Cleft Palate Craniofac J 1998;35 (2):95-100.

[60] Bardach J, Morris HL, Olin WH. Late results of primary veloplasty: the Marburg Project. Plast Recons Surg 1984;73 (2):207-18.

[61] Friede H, Enemark H. Long-term evidence for favorablemidfacial growth after delayed hard palate repair in uclp patients. Cleft Palate Craniofac J 2001;38 (4):323-9.

[62] Sadove AM, Van Aalst JA, Culp JA. Cleft palate repair: art and issues. Clin Plast Surg 2004;31 (2):231-41.

[63] Weinfeld AB, Hollier LH, Spira M, et al. International trends in the treatment of cleft lip and palate. Clin Plast Surg 2005;32 (1):19-23, vii.

[64] Witzel MA, Salyer KE, Ross RB. Delayed hard palate closure: the philosophy revisited. Cleft Palate J 1984;21 (4):263-9.
[65] Slaughter WB, Brodie AG. Facial clefts and their surgical management in view of recent research. Plast Reconstr Surg 1949;4:203-24.

[66] The-influence-of-simultaneous-cleft-lip-and-palaterepair-on-facial-growth-in-rabbits.pdf [cited 2019 Apr 8]. https://www.researchgate.net/profile/Mark_Mooney3/ publication/16265080_The_influence_of_simultaneous_c left_lip_and_palate_repair_on_facial_growth_in_rabbits/li nks/5480c17e0cf20f081e72688b/The-influence-ofsimultaneous-cleft-lip-and-palate-repair-on-facialgrowth-in-rabbits.pdf

[67] Hayashi I, Sakuda M, Takimoto K, et al. Craniofacial growth in complete unilateral cleft lip and palate: a roentgeno-cephalometric study. Cleft Palate J 1976;13:215-37.

[68] Krogman WM, Mazaheri M, Harding RL, et al. A longitudinal study of the craniofacial growth pattern in children with clefts as compared to normal, birth to six years. Cleft Palate J 1975;12:59-84.

[69] Shibasaki Y, Ross RB. Facial growth in children with isolated cleft palate. Cleft Palate J 1969;6 (3):290-302.

[70] Bishara SE, de Arrendondo RS, Vales HP, et al. Dentofacial relationships in persons with unoperated clefts: comparisons between three cleft types. Am J Orthod 1985;87 (6):481-507.

[71] Gillies HD, Fey WK. A new principle in the surgical treatment of "congenital cleft palate" and its mechanical counterpart. Br Med J 1921;1 (3140):335-8.

[72] Fry WK. The dental aspect of the treatment of congenital cleft palates. Proc R Soc Med 1921;14 (Odontol Sect):5768.

[73] Walter JD, Hale V. A study of the long term results achieved by the Gillies Fry procedure. Br J Plast Surg 1987;40 (4):364-90. https://www.sciencedirect.com/science/article/pii/000 7122687900427

[74] Poupard B, Coornaert H, Debaere PA, et al. Cleft lip and palate: can the hard palate be left open? Study of 62 cases with a follow-up of 6 years or more. Ann Chir Plast Esthet 1983;28 (4):325-36.

[75] Rayner HH. The operative treatment of cleft-palate: a record of results in 125 consecutive cases. The Lancet 1925;205 (5303):816-8.

[76] Hagemann R. Uber Spatfolgen des operative $n$ Gaumenspaltenverschlusses. Bruns Beitr Klin Chir 1941;79:573.

[77] Jolleys A. A review of the results of operations on cleft palates with reference to maxillary growth and speech function. Br J Plast Surg 1954;7 (3):229-41.

[78] Robertson NRE, Jolleys A. The timing of hard palate repair. Scandinavian Journal of Plastic and Reconstructive Surgery 1974;8 (1-2):49-51. https://www.tandfonline.com/doi/abs/10.3109/02844 317409084370

[79] Robertson NRE, Jolleys A. A further look at the effects of delaying repair of the hard palate. In: First International Meeting of the Craniofacial Society of Great Britain, Birmingham, UK. 1983.

[80] Koberg W, Koblin I. Speech development and maxillary growth in relation to technique and timing of palatoplasty. J Maxillofac Surg 1973;1 (1):44-50. 
[81] Aduss H. Craniofacial growth in complete unilateral cleft lip and palate. Angle Orthod 1971;41 (3):202-13.

[82] Krause CJ, Tharp RF, Morris HL. A comparative study of results of the von Langenbeck and the V-Y pushback palatoplasties. Cleft Palate J 1976;13:11-9.
[83] Masters FW, Levin JM. Surgical management of the palatal cleft by VY technique (Wardill-Kilner repair). In: Symposium on management of cleft lip and palate and associated deformities. St. Louis: Mosby 1974: p. 165-9. 